The University of San Francisco

USF Scholarship: a digital repository@ Gleeson Library |

Geschke Center

2008

\title{
Methods for Detection of Matrix Metalloproteinases as Biomarkers in Cardiovascular Disease
}

Viorica Lopez-Avila

Juliet Spencer

University of San Francisco, jspencer@usfca.edu

Follow this and additional works at: http://repository.usfca.edu/biol_fac

Part of the Biology Commons, and the Cardiovascular Diseases Commons

\section{Recommended Citation}

Lopez-Avila, V and Spencer, JV. Methods for Detection of Matrix Metalloproteinases as Biomarkers in Cardiovascular Disease. Clinical Medicine Insights: Cardiology 2008:2 75-87.

This Article is brought to you for free and open access by the Biology at USF Scholarship: a digital repository @ Gleeson Library | Geschke Center. It has been accepted for inclusion in Biology Faculty Publications by an authorized administrator of USF Scholarship: a digital repository @ Gleeson Library $\mid$ Geschke Center. For more information, please contact repository@usfca.edu. 


\title{
Methods for Detection of Matrix Metalloproteinases as Biomarkers in Cardiovascular Disease
}

\author{
Viorica Lopez-Avila ${ }^{1}$ and Juliet V. Spencer ${ }^{2}$ \\ ${ }^{1}$ Agilent Technologies, Santa Clara, CA 95051, U.S.A. ${ }^{2}$ University of San Francisco, San Francisco, \\ CA 94403, U.S.A.
}

\begin{abstract}
Matrix metalloproteinases (MMPs) are a family of zinc-dependent proteolytic enzymes that degrade extracellular matrix (ECM) components like collagen, fibronectin, and laminin. While this activity is important for normal development, morphogenesis, and wound healing, deregulation of MMP activity has been implicated in a number of cardiovascular diseases, including congenital heart defects, atherosclerosis, myocardial infarction, and congestive heart failure. MMPs are good potential diagnostic indicators of cardiovascular disease, but current detection methods are time consuming and quite laborious. This review will discuss MMP biology, current methods for detection of MMPs from patient samples, and potential new developments in multiplexed analysis of MMPs.
\end{abstract}

Keywords: matrix metalloproteinases, MMPs, analytical methods, cardiovascular disease

\section{MMP Biology}

Extracellular enzymes play a crucial role in the interaction between cells and their environment. Matrix metalloproteinases (MMPs) are a family of zinc-dependent proteolytic enzymes important in the degradation and turnover of extracellular matrix (ECM) components like collagen (Visse and Nagase, 2003). Since the initial description of collagenolytic activity in tadpole tail resorption (Gross and Lapiere, 1962), MMPs have been shown to function in tissue remodeling, embryonic development, morphogenesis, reproduction, cell-cell adhesion, migration and invasion, and growth factor and cytokine signaling (Nagase and Woessner, 1999). There are five major types of MMPs that were initially categorized according to substrates, including collagenases, gelatinases, stromelysins, matrilysins, and membranetype MMPs (Folgueras et al. 2004). It is now known that many MMPs have multiple substrates, and the current nomenclature uses a numerical system in which these enzymes are classified by domain structure rather than by substrate. To date, twenty-four different MMPs have been identified, based largely on sequence homology with collagenase-1 (MMP-1). Table 1 contains a list of MMPs, including the current name, the old substrate-based name, information about the molecular features of the enzyme, and possible roles in human physiology for each enzyme. Figure 1 shows a schematic diagram of the MMP structure showing the arrangement of the various domains.

Each MMP consists of a specific domain sequence which includes the signal peptide, the pro-peptide domain, the catalytic domain, and the C-terminal hemopexin-like domain, which is present in almost all MMPs. Several MMPs (e.g. MMP-14, -15, -16, and -24) have additional domains such as a transmembrane and a cytoplasmic tail (Nagase and Woessner, 1999). MMPs are typically found in an inactive pro-enzyme form known as a zymogen, and cleavage of the pro-peptide domain yields the active proteinase. The pro-peptide domain is part of a cysteine switch motif that contains the conserved amino acid sequence PRCGXPD; this maintains the enzyme in an inactive form by interacting with the zinc ion at the active site and preventing binding of the substrate (Van Wart and Birkedal-Hansen, 1990; Becker et al. 1995). The catalytic domain contains the catalytic zinc ion bound by three histidine residues in conserved sequence HEXGHXXGXXH. X-ray crystallography and nuclear magnetic resonance have determined the three-dimensional structure of the catalytic domain to contain a fivestranded $\beta$-pleated sheet, three $\alpha$-helices, and connective loops (Visse and Nagase, 2003). In addition to the catalytic zinc ion, the catalytic domain generally contains one structural zinc ion and one or more calcium ions (Bode et al. 1999). The catalytic domain is connected to the hemopexin-like domain by a flexible hinge region that is variable in length. The hemopexin-like domain is located at the

Correspondence: Viorica Lopez-Avila, Ph.D., Agilent Technologies, 5301 Stevens Creek Blvd, Santa Clara, CA 95051, U.S.A. Tel: 408-553-2709; Email: viorica_lopez-avila@agilent.com

Copyright in this article, its metadata, and any supplementary data is held by its author or authors. It is published under the Creative Commons Attribution By licence. For further information go to: http://creativecommons.org/licenses/by/3.0/. 


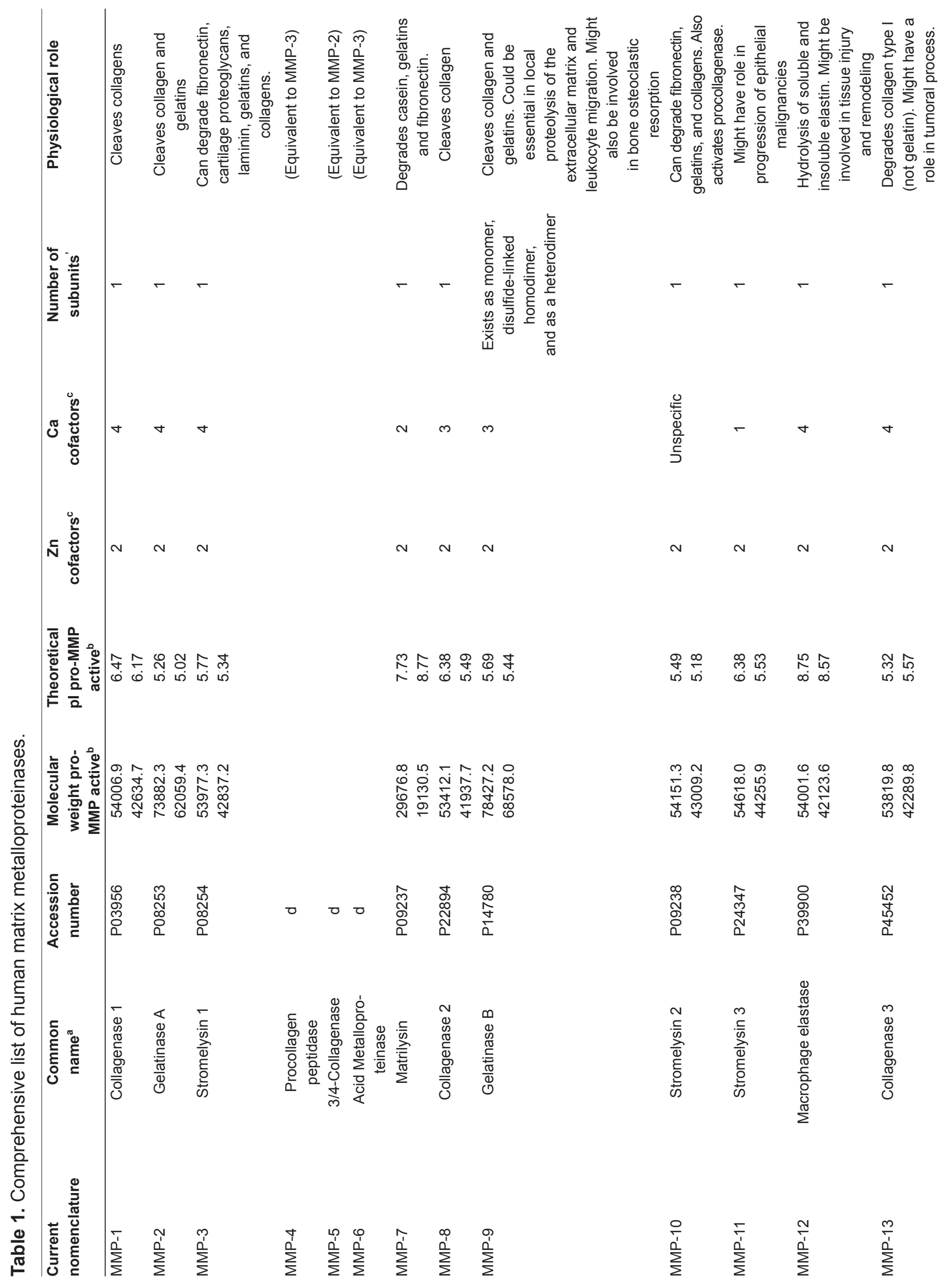



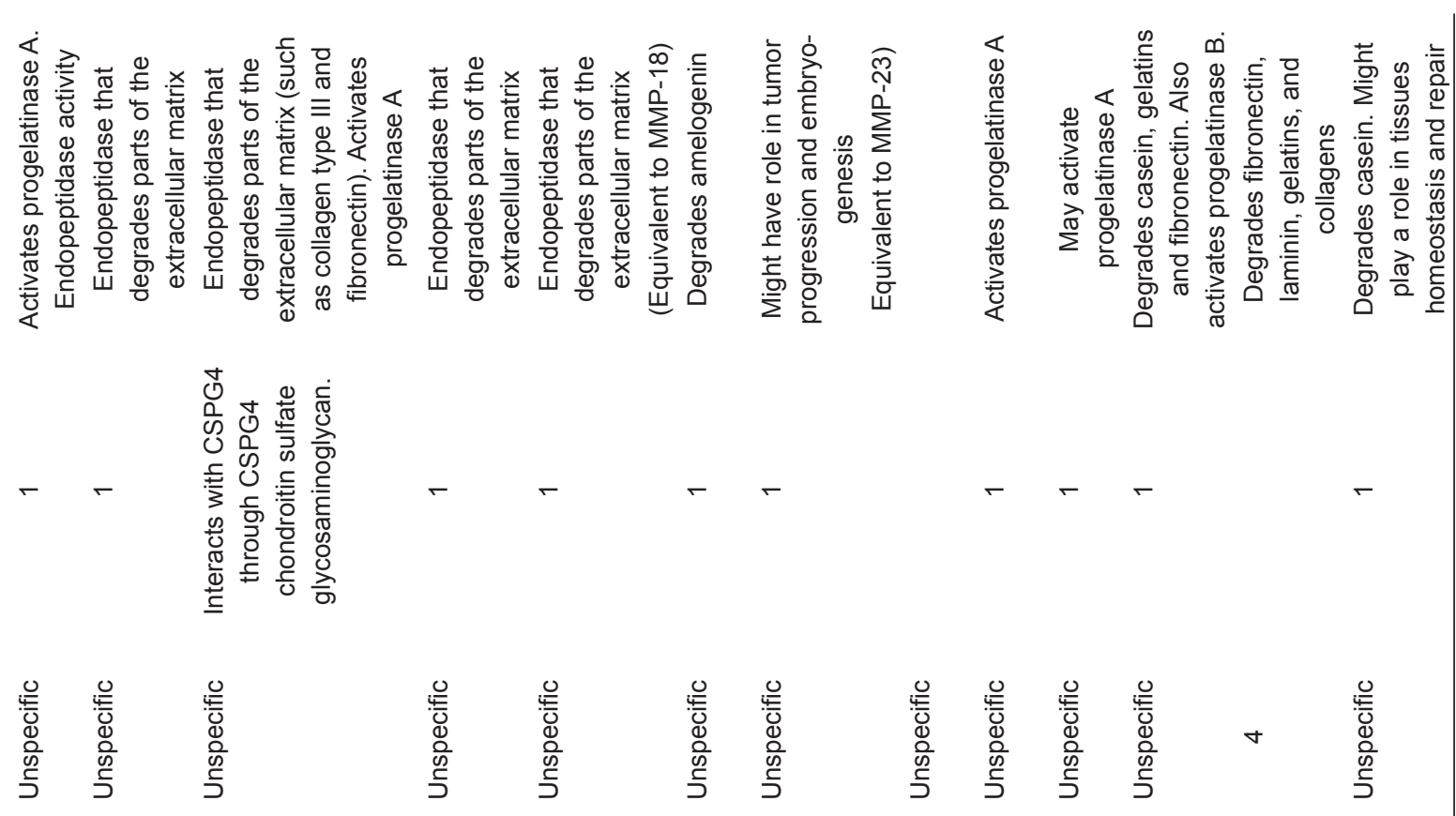

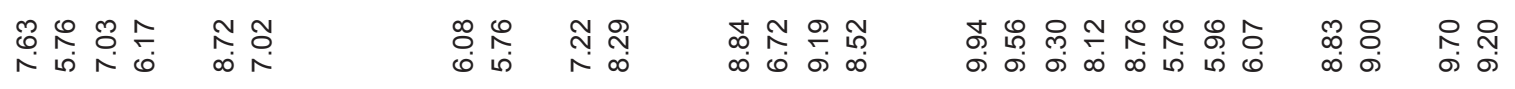

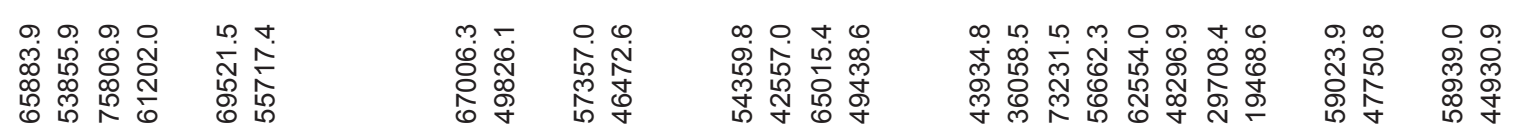

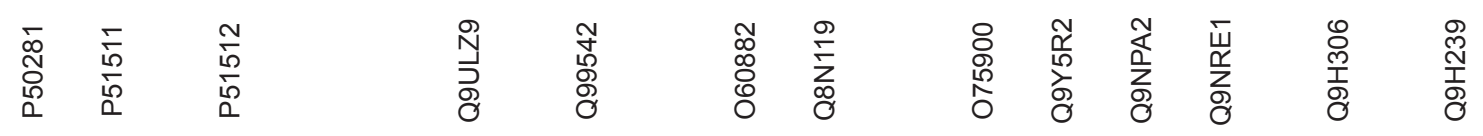
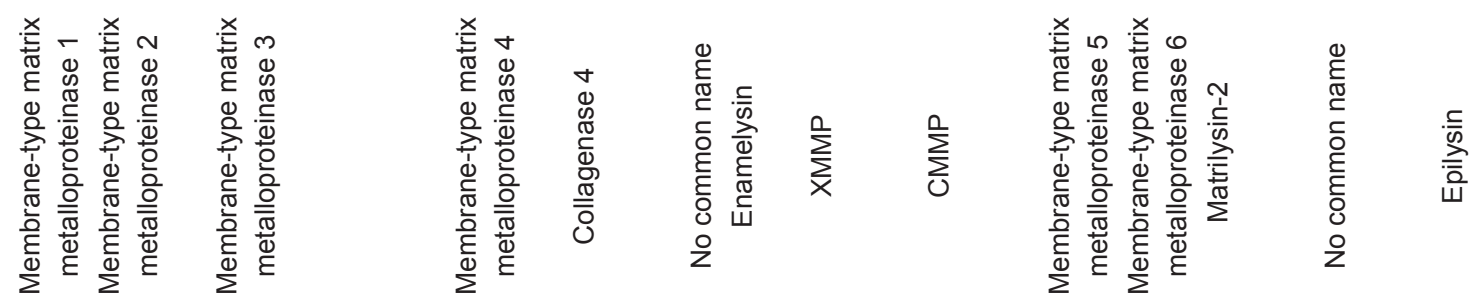

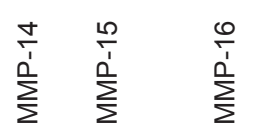

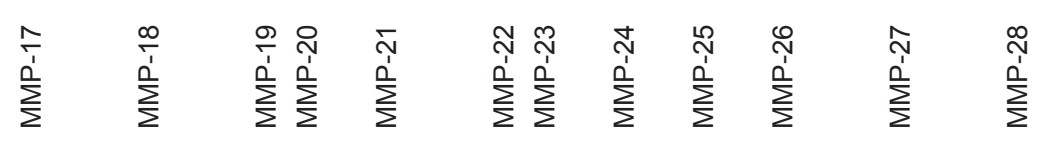


C-terminus of the protein. This region is named for its structural similarities to the serum glycoprotein hemopexin, which binds to heme groups and helps prevent oxidative stress. The hemopexin domain found in MMPs has a four-bladed $\beta$ propeller fold containing a stabilizing disulfide linkage between blades I and IV (Cha et al. 2002). These domains typically mediate protein-protein interactions and are likely to contribute to substrate specificity for each MMP (Overall, 2002).

MMPs are generally secreted as pro-enzymes requiring cleavage in order to be activated. In vivo, activation commonly occurs through interaction with plasmin or via interaction with other proteinases (Lijnen, 2001). MMP activity can also be controlled by a series of endogenous inhibitors, including $\alpha 2$-macroglobulin in the plasma (Cawston and Mercer, 1986) and TIMPs (tissue inhibitors of metalloproteinases) in the tissues. Four TIMPs are currently known to form complexes with MMPs and inhibit enzyme activity (Visse and Nagase, 2003). The overall ratio of TIMPs levels to MMPs levels are thought to be a major determinant of MMP activity. TIMPs generally consist of an $\mathrm{N}$-terminal domain and smaller C-terminal domain connected by a ridge-like loop structure (Fig. 1B). Both the N-terminal and C-terminal domains contain several disulfide bridges, and the entire molecule forms a wedge structure that inserts into the active site of the MMP, inhibiting enzyme activity. In addition, MMP activity may be inhibited by several other molecules, including the $\mathrm{NC1}$ domain of type IV collagen (Petitclerc et al. 2000), tissue factor pathway inhibitor-2 (Herman et al. 2001), and RECK (reversion-inducing cysteine-rich protein with kazal motifs) (Oh et al. 2001; Liu et al. 2003). The extensive and complex regulation of MMPs highlights their important role in normal human physiology.

Deregulation of MMPs has been implicated in a wide variety of human diseases, most notably in tumor progression and metastasis for several forms of cancer, particularly breast (Duffy et al. 2000; Yoon et al. 2003; Folgueras et al. 2004; Stuelten et al. 2005; Jinga et al. 2006), ovarian (Kim et al. 2006), and gastric carcinomas (Torii et al. 1997) . Other pathologies associated with inappropriate MMP activity include rheumatoid arthritis (Maeda et al. 1995; Brennan et al. 1997; Yamanaka et al. 2000), hepatitis (Lichtinghagen et al. 2000; Koulentaki et al. 2002), and osteoarthritis of the hip (Masuhara et al. 2002). In addition, MMPs have been recognized as having significant roles in the development of a wide range of cardiovascular

A

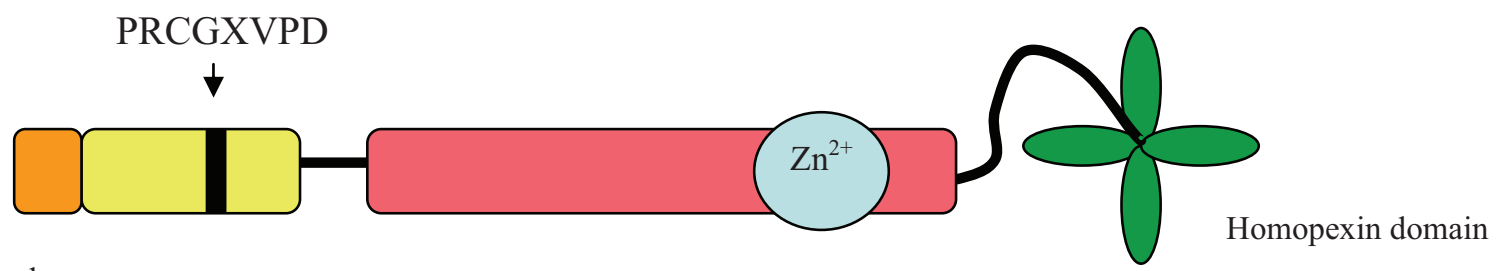

Signal
sequence Propeptide Catalytic domain $\quad$ Hinge region

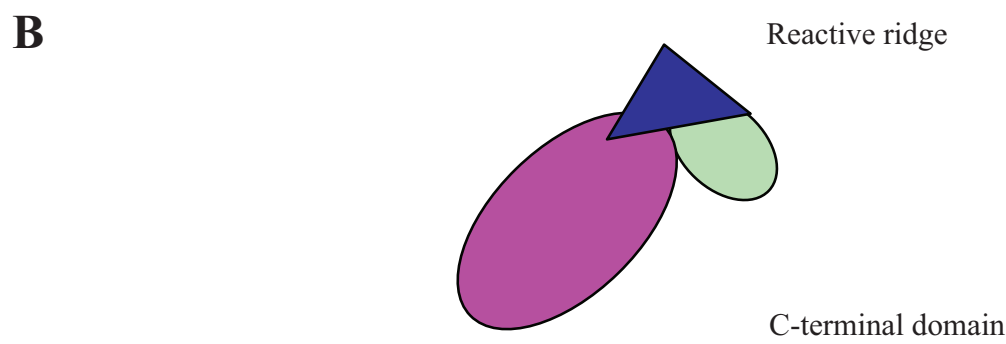

N-terminal domain

Figure 1. Schematic diagram of MMP domain structure (A). TIMP domain structure (B). 
diseases, including congenital heart defects (Brauer, 2006), atherosclerosis (Galis et al. 1994; Kalela et al. 2002; Watanabe and Ikeda, 2004), and myocardial infarction (Kai et al. 1998; Zhao et al. 2005). The concentrations of MMPs found in patient samples in some of these diseases are shown in Table 2. Whether MMPs can be used as reliable indicators of disease state or not remains to be seen and will likely depend on advances in analytical detection methods.

\section{MMPs in Cardiovascular Disease}

Each year more than 25,000 babies in the United States are born in with congenital heart defects. During embryogenesis, the formation of the heart and vasculature requires extensive cell migration, proliferation, and organization into three-dimensional networks, and MMPs are key regulators of these processes. MMP-2 is one of the earliest MMPs known to be expressed during heart development (Cai et al. 2000). Neutralizing antibodies for MMP-2 or the use of broad spectrum MMP inhibitors led to severe heart tube defects in avian embryos (Linask et al. 2005). Midline fusion was prevented and cardiac bifida occurred because the MMP-2 inhibition, suggesting a crucial role for this enzyme in normal cardiac development. Additional studies are required to understand the extent of MMP involvement in embryonic cardiovascular development and the degree to which they contribute to congenital defects.

A growing body of evidence indicates that increased MMP activity plays a role in the development of adult cardiovascular disease. Atherosclerosis occurs when injury to the endothelial lining leads to accumulation of lipids and infiltration of activated monocytes, leading to formation of a plaque. MMP activity, mainly from activated vascular macrophages, may contribute to either plaque formation or the rupturing of plaques leading to coronary occlusion, or both (Watanabe and Ikeda, 2004). Atherosclerotic plaques were found contain significantly higher quantities of activated MMP-2 than non-atherosclerotic tissue extracts (Galis et al. 1994), and subjects with acute coronary syndrome have increased plasma levels of MMP-1, -2, and -9 (Palazzuoli et al. 2006). MMP-8 concentrations were reported to be higher in patients with coronary artery disease (CAD) compared to those without $\mathrm{CAD}$, and MMP-8 levels were also increased with the number of stenotic vessels (Kai et al. 1998). Another study involving patients with coronary atherosclerosis indicated similar findings for MMP-9 (Kalela et al. 2002); serum concentrations were highest in patients with 3-vessel CAD (see Table 2 for 1- and 2-vessel $\mathrm{CAD}$ ), and the difference remained statistically significant after adjustment for age, diabetes, and sex $(p=0.025)$. MMP-9 was reported to be a novel predictor of CAD mortality based on a study involving 1127 patients with documented CAD (Blankenberg et al. 2003); the results showed that 97 patients who died from cardiovascular causes had a median concentration of serum MMP-9 of 62.2 $\mathrm{ng} / \mathrm{mL}$ as compared to $47.8 \mathrm{ng} / \mathrm{mL}$ for those who did not have a fatal cardiovascular event $(p=0.0001)$. MMP-9 and TIMP-1 concentrations were found to decrease and increase, respectively, across the coronary sinus (Inokubo et al. 2001).

In in-vivo studies using apolipoprotein E-deficient mice, over-expression of activated MMP-9 by tissue macrophages enhanced the incidence of plaque rupture (Gough et al. 2006). In direct contrast, increased plaque rupturing was observed in apoE/MMP-9 double knockout mice, suggesting that MMP-9 might normally play a protective role in plaque stabilization (Johnson et al. 2005). The same study demonstrated that MMP-12 might contribute to atherosclerotic lesion expansion and destabilization, as lesion size was reduced in apoE/MMP-12double knockout mice compared to controls. Given the size of the MMP family, their overlapping substrates and numerous inhibitors, it is challenging to clarify the role of individual MMPs in the disease process.

\section{Critical issues in the analysis of MMPs}

The critical issues when developing analytical tools for biomarker analysis include sample integrity, and dealing with different dimensions of complexity (i.e. complexity determined by the tissue origin, complexity due to the number of biomarkers that are being monitored to determine the progression of disease). It is especially important to take note of the methods and conditions under which the sample is collected. As shown in Table 2, there was a large variability in the MMP concentrations reported in the literature. Most of the researchers took samples either from blood plasma or serum. Some recommended heparin plasma to study MMPs (Jung et al. 1996; Yamanaka et al. 2000; Jung et al. 2001; Mannello, 2003; Meisser et al. 2005) because clot activator appears to release MMPs from cells. 
Table 2. Concentrations of MMPs in selected human pathologies.

\begin{tabular}{|c|c|c|c|c|}
\hline \multirow[t]{2}{*}{ MMP } & \multirow[t]{2}{*}{ Disease } & \multicolumn{2}{|l|}{ Concentration } & \multirow[t]{2}{*}{ References } \\
\hline & & Human serum & $\begin{array}{l}\text { Other body fluids } \\
\text { or tissues }\end{array}$ & \\
\hline MMP-1 & $\begin{array}{l}\text { Rheumatoid } \\
\text { Arthritis }\end{array}$ & $25.6(21.9) \mathrm{ng} / \mathrm{mL}$ & $\begin{array}{c}\text { (Synovial fluid) mean } \\
2361 \text { (SD 2628) ng/mL }\end{array}$ & Maeda et al. 1995 \\
\hline MMP-1 & $\begin{array}{l}\text { Rheumatoid } \\
\text { Arthritis }\end{array}$ & $6-10 \mathrm{ng} / \mathrm{mL}$ & & Brennan et al. 1997 \\
\hline MMP-3 & $\begin{array}{l}\text { Rheumatoid } \\
\text { Arthritis }\end{array}$ & $50-100 \mathrm{ng} / \mathrm{mL}$ & & Brennan et al. 1997 \\
\hline MMP-3 & $\begin{array}{l}\text { Rheumatoid } \\
\text { Arthritis }\end{array}$ & $\begin{array}{l}\text { Healthy men: } 64.5+/- \\
29.4 \mathrm{ng} / \mathrm{mL} \text {; Healthy women: } \\
29.0+/-29.4 \mathrm{ng} / \mathrm{mL} \text {; Early } \\
\text { RA: } 246.4+/-267.7 \mathrm{ng} / \mathrm{mL} ; \\
\text { late RA: } 224.6+/-237.3 \mathrm{ng} / \mathrm{mL}\end{array}$ & & Yamanaka et al. 2001 \\
\hline MMP-9 & $\begin{array}{c}\text { Coronary } \\
\text { Atherosclerosis }\end{array}$ & $\begin{array}{c}\text { Control: } 32.2+/-16.1 \mathrm{ng} / \mathrm{mL} \\
(p=0.007) 3 \text {-vessel CAD: } \\
57.3+/-39.1 \mathrm{ng} / \mathrm{mL} \\
(p=0.011) 1-\text { or } 2-\text { vessel } \\
\text { CAD: } 40.4+/-25.1 \mathrm{ng} / \mathrm{mL} \\
(p=0.044)\end{array}$ & & Kalela et al. 2002 \\
\hline MMP-9 & $\begin{array}{l}\text { Acute myocardial } \\
\text { infarction }\end{array}$ & $\begin{array}{c}\text { Control: } 27+/-8 \mathrm{ng} / \mathrm{mL} \\
\text { Acute } \mathrm{Ml}: 87+/-26 \mathrm{ng} / \mathrm{mL}\end{array}$ & & Kai et al. 1998 \\
\hline MMP-9 & $\begin{array}{l}\text { Acute myocardial } \\
\text { infarction }\end{array}$ & & $\begin{array}{c}\text { Control: } 22+/-6 \mathrm{ng} / \mathrm{mL} \\
\text { Monocytes: } 192+/- \\
40 \mathrm{ng} / \mathrm{mL}\end{array}$ & Zhao et al. 2005 \\
\hline MMP-2 & Hepatitis & $\begin{array}{c}\text { (proenzyme) } \\
\text { Healthy: } 752+/-152 \text { ug/L } \\
\text { CAH: } 649+/-168 \text { ug/L }\end{array}$ & & Lichtinghagen et al. 2000 \\
\hline MMP-9 & Hepatitis C & $\begin{array}{l}\text { Healthy: } 455+/-185 \text { ug/L; } \\
\text { CAH MMP9: } 293+/- \\
226 \text { ug/L; }\end{array}$ & & Lichtinghagen et al. 2000 \\
\hline MMP-1 & $\begin{array}{l}\text { Acute viral } \\
\text { hepatitis }\end{array}$ & $\begin{array}{c}\text { Healthy: } 121.8+/-18.3 \mathrm{ng} / \mathrm{mL} ; \\
\text { Hepatitis: } 75.8+/- \\
11.8 \mathrm{ng} / \mathrm{mL} ;\end{array}$ & & Koulentaki et al. 2002 \\
\hline$M M P-2^{a}$ & $\begin{array}{l}\text { Acute viral } \\
\text { hepatitis }\end{array}$ & $\begin{array}{l}\text { Healthy: } 1555+/-133 \mathrm{ng} / \mathrm{mL} \text {; } \\
\text { Hepatitis: } 789.6+/-68 \mathrm{ng} / \mathrm{mL}\end{array}$ & & Koulentaki et al. 2002 \\
\hline$M M P-2^{b}$ & $\begin{array}{l}\text { Acute viral } \\
\text { hepatitis }\end{array}$ & $\begin{array}{l}\text { Healthy: } 425+/-14 \mathrm{ng} / \mathrm{mL} \\
\text { Hepatitis: } 261+/-14 \mathrm{ng} / \mathrm{mL}\end{array}$ & & Koulentaki et al. 2002 \\
\hline MMP-3 & $\begin{array}{l}\text { Acute viral } \\
\text { hepatitis }\end{array}$ & $\begin{array}{l}\text { Healthy: } 21.2+/-5.2 \mathrm{ng} / \mathrm{mL} \text {; } \\
\text { Hepatitis: } 5.2+/-3.4 \mathrm{ng} / \mathrm{mL}\end{array}$ & & Koulentaki et al. 2002 \\
\hline MMP-9a & $\begin{array}{l}\text { Acute viral } \\
\text { hepatitis }\end{array}$ & $\begin{array}{l}\text { Healthy: } 65.1+/-9.4 \mathrm{ng} / \mathrm{mL} \text {; } \\
\text { Hepatitis: } 33.9+/-6.9 \mathrm{ng} / \mathrm{mL}\end{array}$ & & Koulentaki et al. 2002 \\
\hline MMP-9 $9^{b}$ & $\begin{array}{l}\text { Acute viral } \\
\text { hepatitis }\end{array}$ & $\begin{array}{l}\text { Healthy: } 5.8+/-0.34 \mathrm{ng} / \mathrm{mL} \\
\text { Hepatitis: } 2.7+/-0.16 \mathrm{ng} / \mathrm{mL}\end{array}$ & & Koulentaki et al. 2002 \\
\hline MMP-1 & $\begin{array}{l}\text { Osteoarthritis } \\
\text { of the hip }\end{array}$ & $\begin{array}{l}\text { Healthy: } 2.2-22.9 \mathrm{ng} / \mathrm{mL} ; \\
\text { OA: range } 23.5-1850 \\
\text { mean } 351+/-538 \mathrm{ng} / \mathrm{mL} ;\end{array}$ & & Masuhara et al. 2002 \\
\hline MMP-2 & $\begin{array}{l}\text { Osteoarthritis } \\
\text { of the hip }\end{array}$ & $\begin{array}{l}\text { Healthy: } 367-770 \mathrm{ng} / \mathrm{mL} ; \\
\text { OA: range } 63-1670, \mathrm{mean} \\
562.92+/-442.53 \mathrm{ng} / \mathrm{mL}\end{array}$ & & Masuhara et al. 2002 \\
\hline MMP-3 & $\begin{array}{l}\text { Osteoarthritis } \\
\text { of the hip }\end{array}$ & $\begin{array}{l}\text { Healthy: } 15-72 \mathrm{ng} / \mathrm{mL} ; \\
\text { OA: range } 12.5-636 \\
\text { mean } 114+/-176 \mathrm{ng} / \mathrm{mL}\end{array}$ & & Masuhara et al. 2002 \\
\hline
\end{tabular}

(Continued) 
Table 2. (Continued).

\begin{tabular}{|c|c|c|c|c|}
\hline \multirow[t]{2}{*}{ MMP } & \multirow[t]{2}{*}{ Disease } & \multicolumn{2}{|l|}{ Concentration } & \multirow[t]{2}{*}{ References } \\
\hline & & Human serum & $\begin{array}{c}\text { Other body fluids } \\
\text { or tissues }\end{array}$ & \\
\hline MMP-9 & $\begin{array}{l}\text { Osteoarthritis } \\
\text { of the hip }\end{array}$ & $\begin{array}{c}\text { Healthy: } 12-71 \mathrm{ng} / \mathrm{mL} ; \\
\text { OA: range } 3.1-30.5 \\
\text { mean } 11.05+/-9.42 \mathrm{ng} / \mathrm{mL}\end{array}$ & & Masuhara et al. 2002 \\
\hline MMP-9 & Gastric cancer & & $\begin{array}{c}\text { (Plasma) } \\
\text { Healthy: } 36+/- \\
13 \mathrm{ng} / \mathrm{mL} ; \\
\text { Cancer: } 81+/- \\
53 \mathrm{ng} / \mathrm{mL}\end{array}$ & Torii et al. 1997 \\
\hline MMP-2 & Ovarian cancer & & & $\begin{array}{c}\text { Kim et al. } 2006 \\
\text { Duffy et al. } 2000 \\
\text { Yoon et al. } 2003 \\
\text { Folgueras et al. } 2004 \\
\text { Stuelten et al. } 2005 \\
\text { Jinga et al. } 2006\end{array}$ \\
\hline MMP-3 & Breast cancer & & & \\
\hline
\end{tabular}

${ }^{a}$ measurement by ELISA

${ }^{\mathrm{b}}$ mesurement by zymography

Others have found that buffered citrate is the anticoagulant of choice because it slows down the release of MMPs by blood cells, and thus is not as dependent upon time as other anticoagulants (Coussens et al. 2002; Snoek-van Beurden, 2005; Thrailkill et al. 2005). The effect of blood collection methods on the concentration of MMPs was investigated by Manello who reported 2- to 10-fold higher concentrations of MMP-9 in serum than in heparin- and EDTA-plasma, and found that plastic tubes with a silica gel coated surface, as clot activator, gave even a 2-fold higher concentrations for serum samples (Manello, 2003). Nonetheless, he recommended heparin-plasma because platelet activation and neutrophil mobilization during clotting could produce such differences. Furthermore, he hypothesized that some of the disparity resulted from different storage temperatures when the blood was allowed to clot and the time at which the samples were centrifuged (Mannello et al. 2003). Regarding the storage temperature of human samples, it was reported that after 2 years storage at $-80^{\circ} \mathrm{C}$ the MMP-9 concentration in citrate-plasma dropped by $65 \%$, and it was estimated that only $1 \%$ would remain after 43 months (Rouy et al. 2005). In summary, the concentration of MMPs detected depends greatly on pre-analytical conditions of the blood samples, so great care should be exercised in keeping conditions constant for sample preparation. Additionally, it is also essential to note whether it is desired to measure latent, active, MMP-TIMP complexes, or both latent and active MMPs, because different techniques account for different forms of MMP. Other analytical challenges include the fact that most MMPs are regulated by post-translational mechanisms that make it difficult to identify them with conventional genomic and proteomic tools, and that MMPs are inhibited by endogenous binding proteins such as TIMPs.

\section{Multiplexed profiling of MMPs in biological samples}

Although MMP gene profiling conducted to date is most extensive for cancer, several studies have identified genetic variants associated with cardiovascular disease (Ye, 2006). Flex et al. (2007) found that MMP-1 and MMP-3 gene polymorphisms were significantly associated with peripheral arterial occlusive disease (Flex et al. 2007), and a specific MMP-3 polymorphism was strongly associated with acute myocardial infarction (Abilleira et al. 2006). While MMP genotype profiling may not be the best indicator of disease state, it is possible that polymorphism analysis can help identify patients at high risk or those who are more likely to respond to various therapeutics.

A much better indication of current disease state may be ascertained through detection of specific molecules and protein expression profiles of patient samples. However, these data are typically obtained by enzyme immunoassays and mass spectrometry, 
respectively, which are very tedious processes, despite the latest developments in both technologies. The feasibility of using these methods to monitor MMPs as biomarkers is further complicated by the requirement for specific antibodiesone for capture and one for detection in enzyme immunoassays, and mass spectrometry is not sensitive enough to detect individual proteins that span over fourteen orders of magnitude in concentration in the human serum or plasma. Furthermore, cardiovascular disease likely results when multiple molecules or systems have gone awry, thus such analytical tools that can provide that information reliably and fast would need to be developed.

Currently, analytical methods for the determination of MMPs in biological samples include ELISA (enzyme-linked immunosorbent assays, including multiplexed ELISAs in the form of antibody arrays); zymography; optical methods such as near-IR (infrared) optical imaging, fluorescence, and surface plasmon resonance spectroscopy; the use of active-site probes followed by enzymatic digestion of the captured MMPs, and LC-MS/MS (liquid chromatography-mass spectroscopy) analysis of the digested MMPs.

\section{Enzyme immunoassays}

Of the currently available methods for MMP detection, there are several commercially available ELISA kits (e.g. Biotrack, Fluorokine Multianalyte Profiling and Quantikine HS from R\&D Systems), as well as a Luminex assay (Thrailkill et al. 2005), but these assays yield imprecise and potentially misleading results because they cannot distinguish between the active and latent forms of the enzyme or between specific MMPs and their TIMP complexes (Zucker et al. 1994; Maeda et al. 1995; Brennan et al. 1997; Torii et al. 1997; Yamanaka et al. 2000; Koulentaki et al. 2002; Masuhara et al. 2002; Dandona et al. 2003; Watanabe et al. 2005, Nilsson et al. 2006). Sandwich ELISAs do have greater sensitivity, but they require two different antibodies for each individual MMP, and a separate assay plate must be used for the measurement of each MMP, making for a very time consuming assay. The detection limits for Quantikine HS from R\&D Systems (Nilsson et al. 2006) vary greatly for each MMP (i.e. MMP-2 is $0.37 \mathrm{ng} / \mathrm{mL}$; MMP-3 is $2.35 \mathrm{ng} / \mathrm{mL}$ and MMP-7 is $0.09 \mathrm{ng} / \mathrm{mL}$ ). Multiplexed ELISAs have been reported, but these tend to exhibit high cross-reactivity among various MMPs because these proteins share common domains. A $10 \times 10$ bead matrix (Luminex Corporation) in which each bead contains a specific proportion of a red/orange fluorescent dye was reported for analysis of MMP-1, $-2,-3,-8$, and -9 in plasma (Thrailkill et al. 2005). This assay allowed for simultaneous determination of each of these MMPs, thus eliminating any possible operator error in sampling and also reducing sample volume to only $10 \mu \mathrm{L}$ for all five analytes. When compared to single analyte ELISA, this represented a five-fold reduction in sample volume and makes the assay more amenable to pediatric population (Thrailkill et al. 2005).

A prototype antibody array (Agilent Technologies) consisting of forty capture monoclonal antibodies to human serum proteins, including MMPs, TIMPs, and MMP-TIMP complexes was used to assess the differential protein levels between control ( 7 healthy subjects chosen randomly) and patient (11 subjects with a history of cardiovascular disease) plasma samples taken one hour after the treadmill experiment. Based on the resulting data (Fig. 2), proteins were then arranged in descending order starting with those having higher average levels in the patient group compared to control (above the red horizontal line in the heatmap). Proteins with relatively high average levels in both the control and patient group were placed near the bottom of this listing. Finally, proteins for which the control group had higher average levels than the patient group were ranked at the very bottom (below the red line). In each group, the proteins were further ordered by Gaussian error score so that the proteins with the most different distributions of protein levels between the two sample group are on the top. In the heatmap (Fig. 2A), each row represents color-coded protein levels for each of the thirty three target proteins, and each column represents all protein levels for one sample. Blue indicates the lowest protein level in a given row, and yellow indicates the highest level. Plots in Figure 2B show actual distributions of specific protein levels among the two groups for three proteins with most dramatic difference between the two groups. Below the plots, green x's show protein levels in control group, red x's show protein levels in Treadmill patient groups. Green and red graphs show corresponding normal fits. Among the most differentiating proteins are MMP-2/TIMP-2 complex, MMP-10, MMP-9, TIMP-1 and TIMP-2. Classification analysis using leave one out cross-validation 

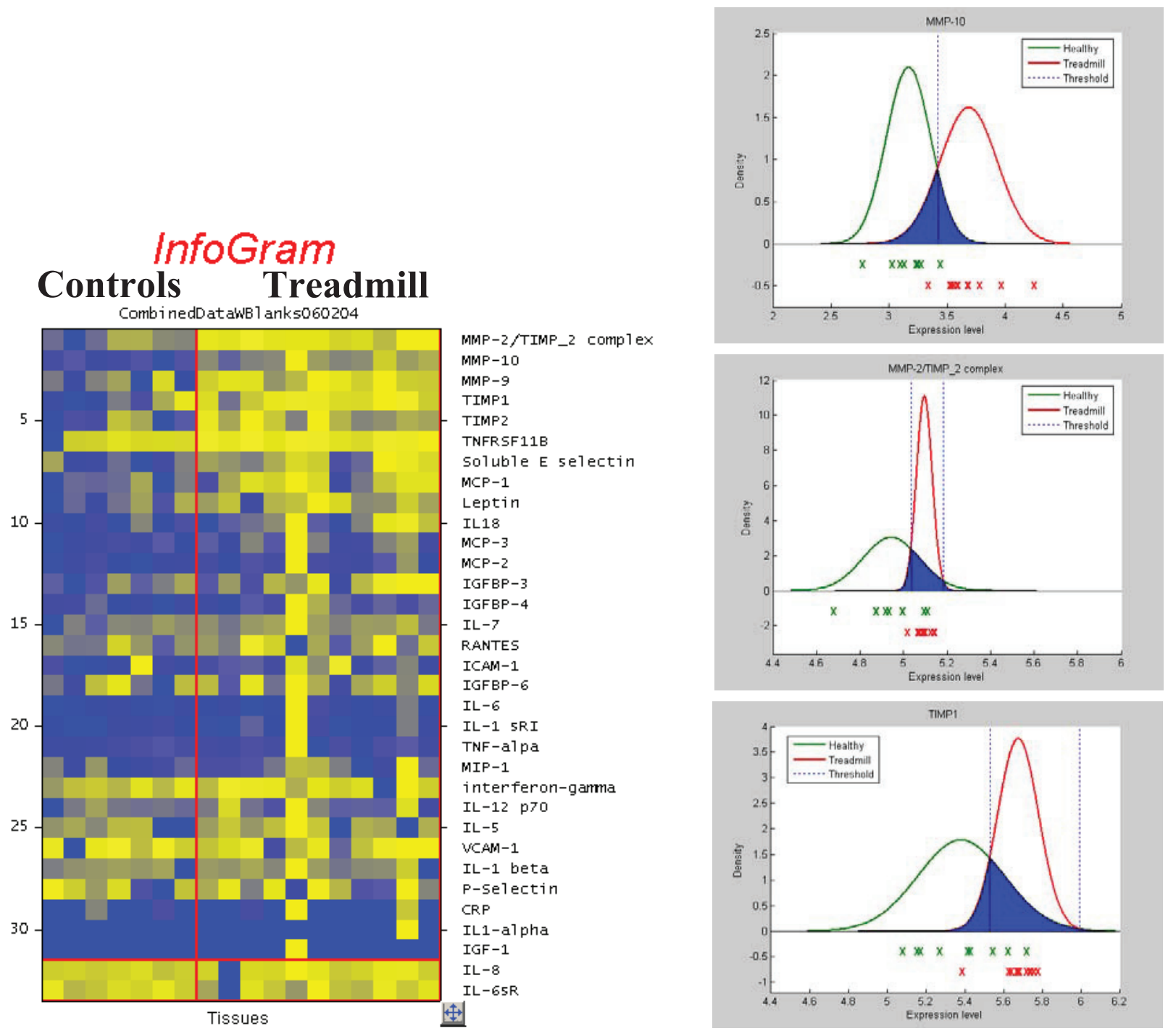

Figure 2. Multiplex analysis of MMP levels in patient samples. Plasma samples collected from subjects from a treadmill study (7 "Controls" and 11 "Treadmill" subjects) were analyzed using a prototype antibody array (Agilent Technologies). A). Heatmap analysis ranking proteins found in the highest concentrations among test subjects compared to control protein levels. Yellow indicated the highest protein levels, blue the lowest. For each patient (11 patients with a history of cardiovascular disease) and control sample (7 healthy subjects chosen randomly), the data shown represents the average of 4 measurements. B) In the Gaussian plots on the right, green shows the individual protein concentrations for control subjects, and red indicates protein levels for patients subjected to the treadmill, with overlap indicated in blue. Values for MMP-10 (top), MMP-2/TIMP-2 complex (middle) and TIMP-1 (bottom) are shown. The antibody array contained 720 features (the 60 monoclonal antibodies and positive and negative controls were printed at two concentrations in quadruplicate) and there were eight identical arrays on the each $1 \times 3$ in modified glass slide. Thirty nine polyclonal antibodies were used as detection antibodies in the assay, and the final step in the detection was accomplished with Cy3-streptavidin.

algorithm showed that one can predict normal or disease status of the sample based on protein levels of top five proteins mentioned above. The data generated with this prototype array is unique because this allows simultaneous determination of thirty nine analytes, including several MMPs and MMP-TIMP complexes, requires only $10 \mu \mathrm{L}$ sample volume, and the amount of antibody present on each feature of the array is
$35 \mathrm{pg}$. This was possible because the arrays were printed using an inkjet deposition tool that delivers $35 \mathrm{pL}$ on each spot with a deviation of only $1-2 \mu \mathrm{m}$ for a spot of $50 \mu \mathrm{m}$ in diameter. Although 60 monoclonal antibodies were deposited onto the array, the multiplexed assay targeted only thirty nine analytes because only thirty nine detection antibodies were working properly in the assay. 


\section{Zymography}

This method is also widely used and identifies MMPs by the degradation of their preferential substrate and by their molecular weight (Snoek-van Beurden, 2005). All types of zymography are similar to gelatin zymography, the substrate simply differs depending on the MMP being analyzed. In zymography, the proteins are separated by electrophoresis under denaturing (in the presence of SDS) and in nonreducing conditions; the separation is done in a polyacrylamide gel that contains the specific substrate. After electrophoresis, the gel is washed to remove SDS, following which the MMPs partially renature and recover their activity. The gel is then stained blue, and the MMPs are visible as clear bands against the blue substrate in the background and can be measured by densitometry (Snoek-van Beurden, 2005). Proenzymes and active forms of MMPs can be distinguished by molecular weight. An added benefit of this method is that it also results in separation of MMP-TIMP complexes (Snoek-van Beurden, 2005). Gelatin zymography is extremely sensitive for gelatinases like MMP-2 and MMP-9 (i.e. 10 pg of MMP-2 can be easily detected) while casein zymography is more suitable for stromelysins MMP-1, -7, -11, -12 , and -13 . Collagen zymography is also used for detection of MMP-1, -2, -9, and -13. In situ zymography, which can detect only active MMPs, allows the localization of MMPs in tissue sections and uses a substrate that is deposited on or under a frozen section of an unfixed tissue sample. In these assays it is important to use control slides with appropriate MMP inhibitors, to discriminate between the different classes of MMPs (Snoek-van Beurden, 2005).

\section{Optical methods}

Near-IR optical imaging has been used primarily for detection of MMPs in tumor tissue (Bremer et al. 2001). An optical contrast agent was developed that was highly activatable by MMP-2induced conversion. Signal characteristics of the probe were measured ex vivo with a recombinant enzyme. Animal tumor models were established with MMP-2-positive (human fibrosarcoma cell line, $n=4$ ) and MMP-2-negative (well-differentiated mammary adenocarcinoma, $n=4$ ) tumor cell lines. Both tumors were implanted into nude mice and were optically imaged after intravenous administration of the MMP-2-sensitive probe (Bremer et al. 2001).
Another optical method, which measures only the MMPs activity and has been used to evaluate MMP inhibitors, is a collagenase assay using capillary gel electrophoresis (CGE) and laser-induced fluorescence detection or LIF (Sano et al. 2004). This collagenase assay employs dynamic fluorescent labeling with NanoOrange dye, and measures fragments of type I and II collagen, which are produced from the native collagen by cleavage with a particular MMP. The CGE-LIF with a capillary array system is ideal as a high throughput system. An assay for detection of both the proform and the active form of MMP-2 with a surface plasmon resonance (SPR) spectrometer, was reported by Pieper-Furst et al. 2004. This assay involves mixing of the MMP-2 with antiMMP-2 antibody adsorbed to colloidal gold and injection into the flowcell of the SPR where TIMP-2 is immobilized. TIMP-2 has at least two binding sites for MMP-2; when the antibody binds the MMP-2 first, one site in MMP-2 is occupied by the antibody, leaving a second site for TIMP. The detection limit for the SPR assay corresponds to $36 \mathrm{pg} / \mathrm{mL}$ and takes only 30 min including the regeneration of the sensor (Pieper-Furst et al. 2004). The SPR assay is not applicable to the detection of the MMP-TIMP complex since TIMP is one of the ligands.

\section{Mass spectrometry}

Identification of MMPs and other metalloproteases with a set of alkyne-tagged hydroxamatebenzophenone (HxBPyne) probes was reported recently (Sieber et al. 2006), and it involves enzymatic digestion after capture of the MMPs using biotin-azide tags and avidin chromatography followed by analysis of the MMP-digests by LC-MS/ MS. The LC-MS/MS method is very lengthy, and it is still not fully reliable when it comes to identifying proteins in the digested form, because the identification often relies on the presence of only a few peptides from the digested protein. Nonetheless, analysis of cell and tissue proteomes treated with an optimal set of probes (i.e. HxBPyne probes) resulted in the identification of more than twenty different metalloproteases (i.e. MMP-1, MMP-3, MMP-7, MMP-12 at detection limits of 0.5, 2.5, 0.25 , and $1 \mu \mathrm{g} / \mathrm{mL}$ of proteome, respectively).

\section{Is there a need for new tools to profile MMPs?}

Although TIMP-1 and TIMP-2 were considered initially as good inhibitors of MMPs in cancer 
progression, it turned out that small molecule inhibitors containing both hydroxamate and nonhydroxamate binding sites were more attractive and five different inhibitors (i.e. Marimastat, Prinomastat, Tanomastat, BMS 275291, and Neovastat) made it into advanced stages of the clinical development with disappointing results. The rapidity with which these inhibitors moved into clinical trials raised a very important question: "Do any MMPs play an important role in advanced lung and pancreatic cancer, and if so, which ones?" (Coussens et al. 2002). Because there is no analytical tool that can answer this question for all twenty-four MMPs measured at the same time, what is really needed is a better tool for multiplexed profiling of this important class of proteins. The data included here for the prototype antibody array demonstrate that MMPs can be reliably measured at $\mathrm{ng} / \mathrm{mL}$ concentrations in human serum, but this array is not yet available commercially and the authors are not aware of any commercial multiplexed ELISA kits that can measure all twenty-four MMPs simultaneously.

One potentially very promising analytical method for profiling all MMPs in a sample under development in the author's laboratory uses two separation steps: immunoaffinity chromatography using an anti-MMP catalytic domain antibody to "fish out" the MMPs from the tissue (i.e. human serum or plasma) and high-pressure liquid chromatography (HPLC) to separate the MMPs as individual proteins (see Fig. 3). These separations are followed by a detection step in which the metal ion (i.e. zinc at mass-to-charge of $66 \mathrm{amu}$ identified here as ${ }^{66} \mathrm{Zn}$ ) is measured by inductivelycoupled plasma mass spectrometry (ICPMS). The ${ }^{66} \mathrm{Zn}$ scan is specific only to MMPs because they are isolated from the sample (i.e. human serum) by immunoaffinity chromatography with an antiMMP antibody. This technique is very powerful in the sense that it can profile all MMPs in one single analysis that can be accomplished in thirty minutes or less. In addition, it is both very sensitive and selective (i.e. compare the UV scan and the ICPMS scans in Figure 3) because it will focus specifically on the metal ion that is at the heart of the protein functionality. For details on the use of HPLC-ICPMS for the identification of metalloproteins, the reader may refer to a paper on determination of ceruloplasmin $(\mathrm{Cp})$, a copper protein, in human serum published by LopezAvila et al. 2006 in which the identification of Cp is based on the retention time match of the unknown in the serum sample with the Cp external standard and the presence of ${ }^{63} \mathrm{Cu}$ and ${ }^{65} \mathrm{Cu}$ at a ratio of $2.2 \pm 0.1$.

Multiplexed analysis of MMPs in biological samples by immunoaffinity chromatography

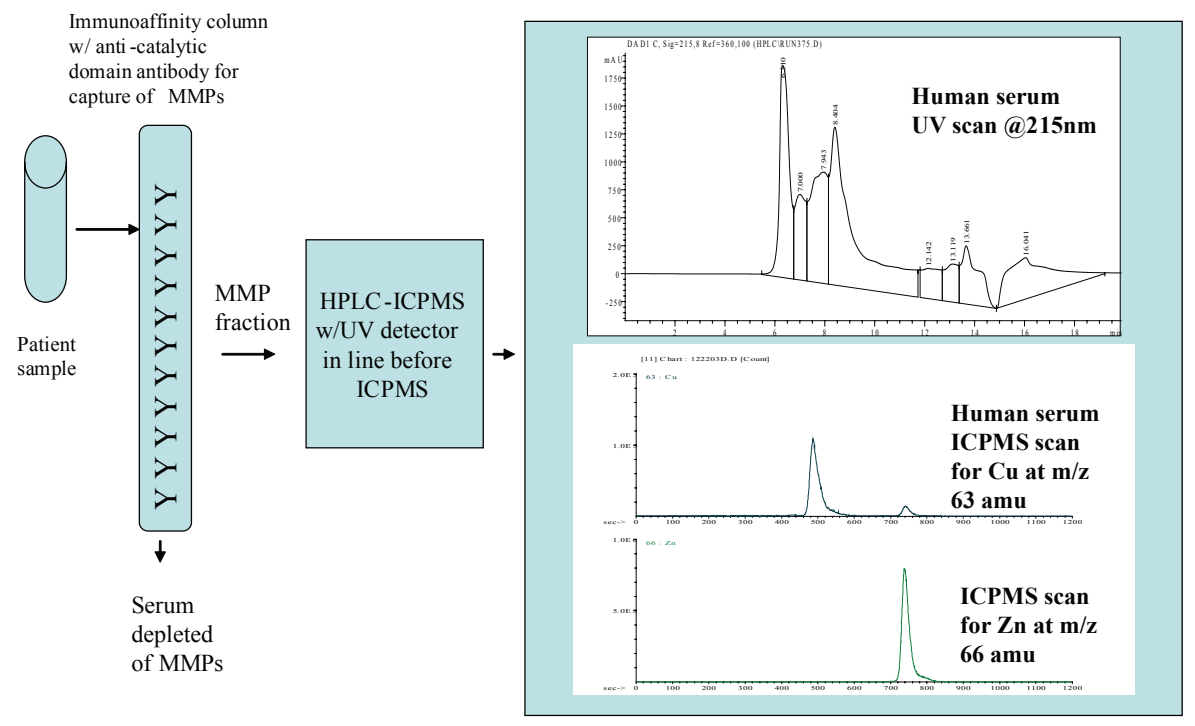

Figure 3. Schematic diagram of the HPLC-ICPMS approach for the determination of MMPs following capture on an immunoaffinity column. The UV scan at $215 \mathrm{~nm}$ shows the presence of a large number of proteins in the human serum. The ICPMS scans for ${ }^{63} \mathrm{Cu}$ and ${ }^{66} \mathrm{Zn}$ show the selectivity of the ICPMS technique in detecting only the metalloprotein(s). The ${ }^{63} \mathrm{Cu}$ peak at scan 500 corresponds to $\mathrm{Cp}$, and the $\mathrm{Zn}$ peak at scan 730 has not been identified yet. The human serum sample shown here has not been processed through an immunoaffinity column, therefore the $\mathrm{Zn}$ scan is not indicative of the presence of MMPs. It is only shown here to demonstrate the selectivity of the ICPMS technique for metalloproteins. 
followed by HPLC-ICPMS is a new concept and has not been reported in the literature for this class of proteins. In this case, MMPs are identified by retention time match with specific MMP standards and by the zinc scan, which is done using the ICPMS system. Because MMPs are "fished-out" from the sample with a reagent that is quite specific for MMPs (i.e. antibodies that recognize the catalytic domain, which is common in all MMPs), this method will generate an MMP fingerprint that can help identify the disease, track disease progression, and help evaluate how therapeutic agents can alter the MMP fingerprint. An MMP fingerprint analyzing levels of all MMPs is crucial, especially because it has been reported that MMP-7, $-8,-9$, and -13 can be inactivated by MMP-3 (Samnegard et al. 2006).

There are difficulties in implementing such approach because many of the MMPs are not available commercially as intact proteins but as recombinant fragments, and they will need to be expressed and purified for such developmental work to be accomplished.

\section{Summary}

MMPs are an important class of enzymes that play roles in both normal physiology and several disease states. Efforts to clarify the importance of particular MMPs in specific pathologies have been hampered by the complex biology of this large family of related enzymes and their TIMP binding partners. In addition, accurate quantitation of multiple of MMPs in patient samples is confounded by limitations of the currently available detection methods. With the further development and commercialization of the HPLC-ICPMS technique, it seems likely that multiple MMPs levels will be able to be more easily monitored and correlated with various aspects of human disease.

\section{Acknowledgements}

The authors acknowledge the contributions of Amber Hess (summer intern) who helped with some of the literature search and Anya Tsalenko of Agilent Technologies who did the computational analysis of the protein array data for selected MMPs.

\section{References}

Abilleira, S., Bevan, S. and Markus, H.S. 2006. The role of genetic variants of matrix metalloproteinases in coronary and carotid atherosclerosis. J. Med. Genet., 43(12):897-901.
Becker, J.W., Marcy, A.I., Rokosz, L.L. et al. 1995. Stromelysin-1: three-dimensional structure of the inhibited catalytic domain and of the C-truncated proenzyme. Protein Sci., 4(10):1966-76.

Blackenberg, S., Rupprecht, H.J., Poirier, O. et al. 2003. Plasma concentration and genetic variation of matrix metalloproteinase 9 and prognosis of patients with cardiovascular disease. Circulation, 107:1579-85.

Bode, W., Fernandez-Catalan, C., Tschesche, H. et al. 1999. Structural properties of matrix metalloproteinases. Cell. Mol. Life Sci., 55(4):639-52.

Brauer, P.R. 2006. MMPs--role in cardiovascular development and disease. Front Biosci., 11:447-78.

Bremer, C., Bredow, S., Mahmood, U. et al. 2001. Optical imaging of matrix metalloproteinase-2 activity in tumors: feasibility study in a mouse model. Radiology, 221(2):523-9.

Brennan, F.M., Browne, K.A., Green, P.A. et al. 1997. Reduction of serum matrix metalloproteinase 1 and matrix metalloproteinase 3 in rheumatoid arthritis patients following anti-tumour necrosis factor-alpha (cA2) therapy. Br. J. Rheumatol., 36(6):643-50.

Cai, D.H., Vollberg, T.M., Hahn-Dantona, Sr. E. et al. 2000. MMP-2 expression during early avian cardiac and neural crest morphogenesis. Anat. Rec., 259(2):168-79.

Cawston, T.E. and Mercer, E. 1986. Preferential binding of collagenase to alpha 2-macroglobulin in the presence of the tissue inhibitor of metalloproteinases. FEBS Lett., 209(1):9-12.

Cha, H., Kopetzki, E., Huber, R. et al. 2002. Structural basis of the adaptive molecular recognition by MMP9. J. Mol. Biol., 320(5):1065-79.

Coussens, L.M., Fingleton, B. and Matrisian, L.M. 2002. Matrix metalloproteinase inhibitors and cancer: trials and tribulations. Science, 295(5564):2387-92.

Dandona, P., Aljada, A., Mohanty, P. et al. 2003. Insulin suppresses plasma concentration of vascular endothelial growth factor and matrix metalloproteinase-9. Diabetes Care, 26(12):3310-4.

Duffy, M.J., Maguire, T.M., Hill, A. et al. 2000. Metalloproteinases: role in breast carcinogenesis, invasion and metastasis. Breast Cancer Res., 2(4):252-7.

Flex, A., Gaetani, E., Angelini, F. et al. 2007. Pro-inflammatory genetic profiles in subjects with peripheral arterial occlusive disease and critical limb ischemia. J. Intern. Med., 262(1):124-30.

Folgueras, A.R., Pendas, A.M., Sanchez, L.M. et al. 2004. Matrix metalloproteinases in cancer: from new functions to improved inhibition strategies. Int. J. Dev. Biol., 48(5-6):411-24.

Galis, Z.S., Sukhova, G.K., Lark, M.W. et al. 1994. Increased expression of matrix metalloproteinases and matrix degrading activity in vulnerable regions of human atherosclerotic plaques. J. Clin. Invest., 94(6):2493-503.

Gough, P.J., Gomez, I.G., Wille, P.T. et al. 2006. Macrophage expression of active MMP-9 induces acute plaque disruption in apoE-deficient mice. J. Clin. Invest., 116(1):59-69.

Gross, J. and Lapiere, C.M. 1962. Collagenolytic activity in amphibian tissues: a tissue culture assay. Proc. Natl. Acad. Sci. U.S.A., 48:1014-22.

Herman, M.P., Sukhova, G.K., Kisiel, W. et al. 2001. Tissue factor pathway inhibitor-2 is a novel inhibitor of matrix metalloproteinases with implications for atherosclerosis. J. Clin. Invest., 107(9):1117-26.

Inobuko, Y., Hanada, H., Ishtzaka, H. et al. 2001. Plasma levels of matrix metalloproteinase-9 and tissue inhibitor of metalloproteinase-1 are increased in patients with acute coronary syndrome. Am. Heart J., 141:211-7.

Jinga, D.C., Blidaru, A., Condrea, I. et al. 2006. MMP-9 and MMP-2 gelatinases and TIMP-1 and TIMP-2 inhibitors in breast cancer: correlations with prognostic factors. J. Cell. Mol. Med., 10(2):499-510.

Johnson, J.L., George, S.J., Newby, A.C. et al. 2005. Divergent effects of matrix metalloproteinases $3,7,9$, and 12 on atherosclerotic plaque stability in mouse brachiocephalic arteries. Proc. Natl. Acad. Sci. U.S.A., 102(43):15575-80. 
Jung, K., Nowak, L., Lein, M. et al. 1996. Role of specimen collection in preanalytical variation of metalloproteinases and their inhibitors in blood. Clin. Chem., 42 (12):2043-4.

Jung, K., Lein, M., Laube, C. et al. 2001. Blood specimen collection methods influence the concentration and the diagnostic validity of matrix metalloproteinase 9 in blood. Clin. Chim. Acta., 314:241-4.

Kai, H., Ikeda, H., Yasukawa, H. et al. 1998. Peripheral blood levels of matrix metalloproteases -2 and -9 are elevated in patients with acute coronary syndromes. J. Am. Coll. Cardiol., 32:368-72.

Kalela, A., Koiyu, T.A., Sisto, T. et al. 2002. Serum matrix metalloproteinase-9 concentration in angiographically assessed coronary artery disease Scandinav. J. of Clin. and Lab. Investig., 62(5):337-42.

Kim, T.J., Rho, S.B., Choi, Y.L. et al. 2006. High expression of tissue inhibitor of metalloproteinase-2 in serous ovarian carcinomas and the role of this expression in ovarian tumorigenesis. Hum. Pathol., 37(7):906-13.

Koulentaki, M., Valatas, V., Xidakis, K. et al. 2002. Matrix metalloproteinases and their inhibitors in acute viral hepatitis. J. Viral Hepat., 9(3):189-93.

Lichtinghagen, R., Huegel, O., Seifert, T. et al. 2000. Expression of matrix metalloproteinase- 2 and -9 and their inhibitors in peripheral blood cells of patients with chronic hepatitis C. Clin. Chem., 46(2):183-92.

Lijnen, H.R. 2001. Plasmin and matrix metalloproteinases in vascular remodeling. Thromb. Haemost., 86(1):324-33.

Linask, K.K., Han, M., Cai, D.H. et al. 2005. Cardiac morphogenesis: matrix metalloproteinase coordination of cellular mechanisms underlying heart tube formation and directionality of looping. Dev. Dyn., 233(3):739-53.

Liu, L.T., Chang, H.C., Chiang, L.C. et al. 2003. Histone deacetylase inhibitor up-regulates RECK to inhibit MMP-2 activation and cancer cell invasion. Cancer Res., 63(12):3069-72.

Lopez-Avila, V., Sharpe, O. and Robinson, W.H. 2006. Determination of ceruloplasmin in human serum by SEC-ICPMS. Anal. Bioanal. Chem., 386:180-7.

Maeda, S., Sawai, T., Uzuki, M. et al. 1995. Determination of interstitial collagenase (MMP-1) in patients with rheumatoid arthritis. Ann. Rheum. Dis., 54(12):970-5.

Mannello, F. 2003. Effects of blood collection methods on gelatin zymography of matrix metalloproteases. Clin. Chem., 49(2):339-40.

Mannello, F., Luchetti, F., Canonico, B. et al. 2003. Effect of anticoagulants and cell separation media as preanalytical determinants on zymographic analysis of plasma matrix metalloproteinases. Clin. Chem., 49(11):1956-7.

Masuhara, K., Nakai, T., Yamaguchi, K. et al. 2002. Significant increases in serum and plasma concentrations of matrix metalloproteinases 3 and 9 in patients with rapidly destructive osteoarthritis of the hip. Arthritis. Rheum., 46(10):2625-31.

Meisser, A., Cohen, M. and Bischof, P. 2005. Concentrations of circulating gelatinases (matrix metalloproteinase-2 and -9) are dependent on the conditions of blood collection. Clin. Chem., 51(1):274-6.

Nagase, H. and Woessner, J.F. 1999. Matrix metalloproteinases. J. Biol. Chem., 274(31):21491-4.

Nilsson, L., Jonasson, L., Nijm, J. et al. 2006. Increased plasma concentrations of matrix metalloproteinase- 7 in patients with coronary artery disease, Clin. Chem., 52(8):1522-7.

Oh, J., Takahashi, R., Kondo, S. et al. 2001. The membrane-anchored MMP inhibitor RECK is a key regulator of extracellular matrix integrity and angiogenesis. Cell., 107(6):789-800.

Overall, C.M. 2002. Molecular determinants of metalloproteinase substrate specificity: matrix metalloproteinase substrate binding domains, modules, and exosites. Mol. Biotechnol., 22(1):51-86.

Palazzuoli, A., Iovine, F., Scali, C. et al. 2006. Acute coronary syndromes: from the laboratory markers to the coronary vessels. Biomarkers Insights, 2:123-30.
Petitclerc, E., Boutaud, A., Prestayko, A. et al. 2000. New functions for non-collagenous domains of human collagen type IV. Novel integrin ligands inhibiting angiogenesis and tumor growth in vivo. J. Biol. Chem., 275(11):8051-61.

Pieper-Furst, U., Kleuser, U., Stocklein, W.F.M. et al. 2004. Detection of subpicomolar concentrations of human matrix metalloproteinase-2 by an optical biosensor. Anal. Biochem., 332:160-7.

Rouy, D., Ernens, I., Jeanty, C. et al. 2005. Plasma storage at $-80{ }^{\circ} \mathrm{C}$ does not protect matrix metalloproteinase- 9 from degradation. Anal. Biochem., 338:294-8.

Samnegard, A., Silveira, A., Tornvall, P. et al. 2006. Lower serum concentration of matrix metalloproteinase-3 (MMP-3) in the acute stage of myocardial infarction. J. Intern. Med., 259:530-6.

Sano, M., Nishino, I., Ueno, K. et al. 2004. Assay of collagenase activity for native triple-helical collagen using capillary gel electrophoresis with laser-induced fluorescence detection. J. Chrom. B., 809:251-6.

Sieber, S.A., Niessen, S., Hoover, H.S. et al. 2006. Proteomic profiling of metalloprotease activities with cocktails of active-site probes. Nat. Chem. Biol., 2(5):274-81.

Snoek-van Beurden, P.A.M and Von den Hoff, J.W. 2005. Zymographic techniques for the analysis of matrix metalloproteinases and their inhibitors. Biotechniques, 38(1):73-83.

Stuelten, C.H., DaCosta Byfield, S., Arany, P.R. et al. 2005. Breast cancer cells induce stromal fibroblasts to express MMP-9 via secretion of TNF-alpha and TGF-beta. J. Cell. Sci., 118(Pt 10):2143-53.

Thrailkill, K.M., Moreau, C.S., Cockrell, G. et al. 2005. Physiological matrix metalloproteinase concentrations in serum during childhood and adolescence, using Luminex Multiplex technology. Clin. Chem. Lab. Med., 43(12):1392-9.

Torii, A., Kodera, Y., Uesaka, K. et al. 1997. Plasma concentration of matrix metalloproteinase 9 in gastric cancer. Br. J. Surg., 84(1):133-6.

Van Wart, H.E. and Birkedal-Hansen, H. 1990. The cysteine switch: a principle of regulation of metalloproteinase activity with potential applicability to the entire matrix metalloproteinase gene family. Proc. Natl. Acad. Sci. U.S.A., 87(14):5578-82.

Visse, R. and Nagase, H. 2003. Matrix metalloproteinases and tissue inhibitors of metalloproteinases: structure, function, and biochemistry. Circ. Res., 92(8):827-39.

Watanabe, M., Asatsuma, M., Ikui, A. et al. 2005. Measurements of several metallic elements and matrix metalloproteinases (MMPs) in saliva from patients with taste disorder. Chem. Senses, 30(2):121-5.

Watanabe, N. and Ikeda, U. 2004. Matrix metalloproteinases and atherosclerosis. Curr. Atheroscler. Rep., 6(2):112-20.

Woessner, J.F. and Nagase, H. 2002. Matrix Metalloproteinases and TIMPs. Oxford University Press, 2.

Yamanaka, H., Matsuda, Y., Tanaka, M. et al. 2000. Serum matrix metalloproteinase 3 as a predictor of the degree of joint destruction during the six months after measurement, in patients with early rheumatoid arthritis. Arthritis Rheum, 43(4):852-8.

Ye, S. 2006. Influence of matrix metalloproteinase genotype on cardiovascular disease susceptibility and outcome. Cardiovasc. Res., 69(3):636-45.

Yoon, S.O., Park, S.J., Yun, C.H. et al. 2003. Roles of matrix metalloproteinases in tumor metastasis and angiogenesis. J. Biochem. Mol. Biol., 36(1):128-37.

Zhao, S.P., Deng, P., Huang, H.G. et al. 2005. Expression of COX-2 mRNA in peripheral blood monocytes from patients with acute myocardial infarction and its significance. Clin. Chem., 51(11):2170-3.

Zucker, S., Mancuso, P., DiMassimo, B. et al. 1994. Comparison of techniques for measurement of gelatinases/type IV collagenases: enzymelinked immunoassays versus substrate degradation assays. Clin. Exp. Metastasis, 12(1):13-23. 